specimens of Potentilla reptans, less than half an inchi in diameter, and even in unexpanded buds, were the pollen-tubes penetrating the stigmas.

I call attention to pollen-tubes, because, unless they be observed, one cannot feel absolutely certain that the flowers are really self-fertilised ; and even then, that fact must be associated with the relative positions of anthers and stigmas, and the resulting abundance of fruit.

Another point I would mention of importance is the necessity of observing the order of ennergence of the whorls. The subsequent rates of growth may prove a source of deception, so that it is necessary to go back to the very earliest condition when the parts are little more than papillæe, and if possible even before one or more of the whorls have put in an appearance at all. Now I find that in conspicuous flowers, with certain exceptions, the corolla is very often the last to emerge, though ultimately it attains by far the largest size when adult; that the stamens usually come directly after the calyx, which, if present, is alwayss first, acting as a protecting and nourishing organ; and that the pistil comes next. Such an order results usually in protandry; but while conspicuous species, as Stellaria Holostea, and Cardamine jratensis, have the order, calyx, stamens, pistil, corolla, inconspicuous selffertilising species are often as follows:-e.g., Cerastium glomeratum-calyx, pistil, stamens, corolla, and Nasturtium officinale, calyx, stamens and pistil (together), corolla. These examples, out of many collected, appear to point to an important connection between the order of emergence and development on the one hand, and cross and self-fertilisation on the other. The connection between these two orders of facts I take to be, as already stated, due to the fact that the energy of conspicuous flowers is diverted into the corolla, which thereby delays the development of the pistil ; but when the corolla is arrested, the pistil recovers itself, and its growth is equal to or precedes that of the stamens, the result issuing in a synchronous maturity, and consequently self-pollination.

7, Bentinck 'Terrace, Regent's Park

GEORGE HENSLOW

Wallace's "Geographical Distribution of Animals"

ALLOw me to point out in NATURE a few errors which occur in Mr. Wallace's "Distribution of Animals," regarding the extinct mammalian fauna of India.

In the first place, there is a mistake regarding the locality of the Perim Island (vol. i., p. 362 , vol. ii., pp. 157 and $22 \mathrm{r}$ ), from which Tertiary fossils have been obtained; in Mr. Wallace's book the Perim Island, at the entrance to the Red Sea, is the one referred to, whereas the true spot is Perim Island, in the Gulf of Cambay.

There is, therefore at present no known spot to the eastward of India which shows the former extension of its Tertiary mam. malia into Africa and Europe, although such extension doubtless existed.

The extinct genus Enhydriodon, from the Siwaliks (e.g. vol. ii., p. 200), is always referred to as Enhydrion.

In vol. i. (p. 122) the genus Tapirus is mentioned as occurring in the Miocene of the Punjab; this determination is on the authority of. Dr. Falconer, who hastily examined a single tooth (now in the Indian Museum); this tooth, and others subsequently found, turns out to belong to the European Miocene genus Listriodon: the only other mentioned occurrence of a fossil Tapir in India, is by Mr. Clift, who figured the symphysis of a mandible (Geol. Trans, sec. ser., vol. ii.) from Burma; this may, however, also belong to Listriodon.

In vol. ii. (p. 202) the genus Ursus is mentioned as having been described from the Siwaliks and the Nerbudda Valley; it has only been described from the latter locality, Hyrnactos heing the Siwalik genus. A new species of tame Ursus has, however, been obtained this year from the Siwaliks, and will be subsequently described.

In vol. ii. (p. 212) Hipparion should also be mentioned as having been found in India as well as in Europe.

At p. 228 of the same volume, it is stated that Elephas has "perhaps one species Pliocene in Central India;" in reality there are two species undoubtedly from the Newer Pliocene of the Nerbudda Valley, viz., E. nomadicus and $E$. (Stegodon) insignis.

Vol. ii., p. 240, the genus Hystrix has been fossil in the Siwaliks of India as well as in Europe and America.

I may add that, as announced in the August number of the "Records of the Geological Survey of India," for the present year, I have determined the existence of a species of Manis (the first fossil species of the genus) and of a Cetacean, with other new forms, from the Siwaliks. RICHARD LYDEXXKER, Calcutta, August 27 Geological Survey of India

\section{The Resistance of the Electric Arc}

For tixe purpose of determining theoretically the best arrange. ment of cells for the production of the electric light, it was neces. sary to know the resistance of the electric arc. Not being acquainted with any source from which this information could be derived, we determined this resistance experimeritally in two distinct ways.

I. The current from sixty new Grove's cells joined in series (and of which the immersed part of each platinum plate was about 13 square inches in area and of each zinc plate about 25 square inches) was used to produce an electric light with a Duboscq's lamp, when a small known resistance consisting of many metres of thick bare copper wire hanging in the air was also introduced in circuit. This wire was suficiently thick for its resistance not to be sensibly altered by the passage of the current. The difference of potentials between the carbons was measured with a Thomson's quadrant electrometer, using the induction plate and compared with the difference of potentials between the two ends of the wire of known resistance. These $t$ wo measurements were made rapidly one after the other and repeated very many times. Then since at any moment the same current is flowing through the electric arc and the wire, the two differences of potentials measured rapidly onc after the other are proportional to the resistances.

The above method showed that the resistance of the electric arc varied considerably even when the light appeared quite steady, that the resistance was never more than $20 \mathrm{obms}$, and had an average value of about 12 ohms.

2. On another occasion the current from eighty similar Grove's cells joined in series, which had been joined up for three hours, and used at intervals during this time for the production of the light, was sent through the coils of a differential galvanometer. In one circuit was a very high resistance and in the other the electric arc; each coil of the differential galvanometer was shumted with a wire of small resistance. Nearly the whole current, therefore, went through the arc. The shunts being properly adjusted to obtain balance, the resistance of the arc, as in the previous case, was found to vary much but never to exceed 29 ohms and to equal about 20 ohms when the light was best.

That the resistance would be larger than in the previous case was to be expected since the battery contained more cells, and a brighter light would, therefore, be obtained with the carbon points further apart.

At a coivenient opportunity we hope to take time readings of the resistance together with photographs of the light on a revolving band of sensitive paper in order to determine the exact resistance corresponding with the brightest light for any particular number of cells.

The results, however, given above show that with cells such as we used, and which are the common Grove's cells employed in England, no attempt should be made to join any of the cells in parallel circuit until at least 200 have been joined in series, for since the resistance of each cell is about $0^{\prime} 2 \mathrm{ohms}, 200$ of them would have a resistance of $40 \mathrm{ohms}$, a resistance certainly less than double the electric are for that battery corresponding with brightest light, and we have shown (Teleyraphic Fournal, March 15, 1873) that the cells of a battery should be joined in series until the battery of resistance is double the external resistance, at which point the battery should be joined in two rows each containing half the whole number of cells in series, and the two rows connected in parallel circtiit.

The Imperial College of Engineering, JOHN PERR Tokio, Japan.

\section{Habits of Animais Transmikted to Offspring}

BREEDING many horses yearly on my station, I notice, as a matter of course, some of their peculiar habits. In ₹ semiwild state on a run horses graze together in large or smail corn* panies, which "station hands" call "mobs;" these mobs wander at will over a large area of country, finding abundance of good natural pasture and water. Some years since a mare became solitary in her habits, always seeking one particular creek; whenever released from work she made off to her favourite feeding ground by herself; if "rounded up with a mob" she would take the earliest chance that presented itself of reaching 